Article

\title{
Clinicopathological Factors Related to Recurrence Patterns of Resected Non-Small Cell Lung Cancer
}

\author{
Reiko Shimizu ${ }^{1}$, Tomomari Kinoshita ${ }^{1, *}$, Naomichi Sasaki ${ }^{1}$, Mao Uematsu ${ }^{1}$, Yusuke Sugita ${ }^{1}$, \\ Toshiyuki Shima ${ }^{1}$, Masahiko Harada ${ }^{1}$, Tsunekazu Hishima ${ }^{2}$ and Hirotoshi Horio ${ }^{1}$ \\ 1 Department of Thoracic Surgery, Tokyo Metropolitan Cancer and Infectious Diseases Center \\ Komagome Hospital, Tokyo 113-8677, Japan; reiko.0908.reiko@gmail.com (R.S.); \\ chimiona.1025@gmail.com (N.S.); m.uematsu0718@gmail.com (M.U.); y.sugita07@gmail.com (Y.S.); \\ hitorimatatabi1983@gmail.com (T.S.); msharada@cick.jp (M.H.); hirohori@cick.jp (H.H.) \\ 2 Department of Pathology, Tokyo Metropolitan Cancer and Infectious Diseases Center Komagome Hospital, \\ Tokyo 113-8677, Japan; hishima@cick.jp \\ * Correspondence: kinotomo0415@gmail.com; Tel.: +81-3-3823-2101; Fax: +81-3-3823-5433
}

Received: 28 June 2020; Accepted: 29 July 2020; Published: 1 August 2020

check for updates

\begin{abstract}
Even after complete resection, non-small cell lung cancer (NSCLC) shows preferential recurrence in the mediastinal lymph nodes, lungs, brain, bone, liver, and adrenal gland. However, the relationship between clinicopathological factors and recurrence patterns after resection has not been well-evaluated. Among 688 NSCLC cases with complete resection between 2004 and 2016, 233 cases recurred at our institute. On multivariate analyses, NSCLCs with lymph node metastasis and pulmonary metastasis at surgery commonly recurred in the mediastinal lymph nodes and lungs, respectively. Young age, adenocarcinoma, and vascular invasion were correlated with brain metastasis. Although no variable was associated with bone metastasis, vascular invasion was correlated with postoperative liver and adrenal gland metastasis. Pathologically proven stage II or III NSCLC, adenocarcinoma, and the presence of lymphatic permeation would result in multiple metastases. Vascular invasion, larger invasive size, and advanced stage were independent risk factors of early recurrence. Considering survival, vascular invasion, elderly age, and non-adenocarcinoma were unfavorable prognostic factors after recurrence. Some clinicopathological variables were correlated with organ-specific metastasis and post-recurrence survival. Particularly, vascular invasion was a biomarker of brain, liver, and adrenal gland metastases and a prognostic marker after recurrence among completely resected NSCLC. This information is useful for more frequent patient follow-up and identifying organ-specific distant metastasis.
\end{abstract}

Keywords: clinicopathological factors; metastasis sites; non-small cell lung cancer

\section{Introduction}

Owing to the use of high-resolution computed tomography (HRCT), small and resectable non-small cell lung cancer (NSCLC) are increasingly being detected worldwide [1,2]. Nevertheless, NSCLC recurrence, even after complete resection, is still frequently observed in clinical settings [3,4]. Many studies have identified some clinicopathological factors that could predict the postoperative prognosis of patients with NSCLC [5-9]. Thus, identifying predictors of recurrence in patients with completely resected NSCLC would be very helpful in determining whether a shorter period systemic evaluation should be performed during follow-up.

Solid tumors have great variations in the patterns of metastatic organ tropism. In other words, a particular cancer tends to relapse to one particular organ or multiple specific organ sites. In general, NSCLC is likely to metastasize to some organs, including the mediastinal lymph nodes, lungs, brain, 
bones, liver, and adrenal glands [10-14]. Although many studies evaluated the relationship between clinicopathological factors and postoperative recurrence, the patterns of recurrence after complete resection have not been well described. Therefore, in the current study, we evaluated the relationship between perioperative clinicopathological factors and recurrence site patterns after complete resection and determined the correlation between these factors and survival after recurrence.

\section{Materials and Methods}

\subsection{Patient Characteristics}

Between January 2004 and December 2016, a total of 688 patients with NSCLC underwent complete resection and systematic lymph node dissection at our institute. For diagnostic work-up, all patients underwent chest contrast-enhanced HRCT and positron emission tomography (PET) CT. When nodal metastasis was suspected, additional examinations were performed, such as endobronchial ultrasound-guided transbronchial needle aspiration or biopsy using mediastinoscopy. All therapies, including surgery, adjuvant chemotherapy, and post-recurrent therapies, were discussed and decided at a multi-disciplinary team conference. Among them, 223 patients had a postoperative recurrence of NSCLC. Patients were excluded if they underwent sublobar resection and/or neoadjuvant chemotherapy and had NSCLC with positive intraoperative pleural lavage cytology. The detailed data of these enrolled patients are shown in Table 1.

Table 1. Clinicopathologic Characteristics of Patients (All cases and recurrence cases).

\begin{tabular}{|c|c|c|}
\hline Factors & All Cases $n=688(\%)$ & Recurrence Cases $n=223(\%)$ \\
\hline sex & $408 / 280$ & $145 / 78$ \\
\hline male/female & $(59 / 41)$ & $(65 / 35)$ \\
\hline $\begin{array}{c}\text { age } \\
\text { median (range) }\end{array}$ & $71(19-91)$ & $69(19-87)$ \\
\hline observation period & $57.3(4-194)$ & $58.5(4-194)$ \\
\hline smoking & $482 / 206$ & $164 / 59$ \\
\hline ever/never & $(70 / 30)$ & $(74 / 36)$ \\
\hline surgery & $653 / 30 / 5$ & $208 / 12 / 3$ \\
\hline lobectomy/bilobectomy/pneumonectomy & $(95 / 4 / 1)$ & $(93 / 5 / 2)$ \\
\hline histological type & $470 / 163 / 14 / 11 / 13 / 17$ & $154 / 45 / 6 / 3 / 5 / 10$ \\
\hline AD/SQ/ADSQ/LA/LCNEC/others & $(68 / 24 / 2 / 2 / 2 / 2)$ & $(69 / 20 / 3 / 1 / 2 / 5))$ \\
\hline invasive size & $409 / 202 / 55 / 22$ & $85 / 96 / 28 / 14$ \\
\hline$<3 \mathrm{~cm} / 3-5 \mathrm{~cm} / 5-7 \mathrm{~cm} / 7 \mathrm{~cm}>$ & $(59 / 30 / 8 / 3)$ & $(38 / 43 / 13 / 6)$ \\
\hline lymphatic permeation & $307 / 381$ & $120 / 103$ \\
\hline present/absent & $(45 / 55)$ & $(54 / 46)$ \\
\hline vascular invasion & $386 / 302$ & $175 / 48$ \\
\hline present/absent & $(56 / 44)$ & $(78 / 22)$ \\
\hline pleural invasion & $143 / 545$ & $130 / 93$ \\
\hline present/absent & $(21 / 79)$ & $(58 / 42)$ \\
\hline pulmonary metastasis & $41 / 647$ & $18 / 205$ \\
\hline present/absent & $(6 / 94)$ & $(8 / 92)$ \\
\hline lymph node metastasis & $496 / 90 / 102$ & $107 / 44 / 72$ \\
\hline $\mathrm{N} 0 / \mathrm{N} 1 / \mathrm{N} 2$ & $(72 / 13 / 15)$ & $(48 / 20 / 32)$ \\
\hline adjuvant therapy & $170 / 518$ & $88 / 135$ \\
\hline performed/undone & $(25 / 75)$ & $(39 / 61)$ \\
\hline pathological stage & $228 / 151 / 44 / 128 / 99 / 38$ & $22 / 41 / 13 / 59 / 58 / 30$ \\
\hline IA/IB/IIA/IIB/IIIA/IIIB & $(33 / 22 / 6 / 19 / 14 / 6)$ & $(10 / 18 / 6 / 26 / 26 / 14)$ \\
\hline
\end{tabular}

$\mathrm{AD}$, adenocarcinoma; SQ, squamous cell carcinoma; ADSQ, adenosquamous carcinoma; LA, large cell carcinoma; LCNEC, large cell neuroendocrine carcinoma.

Data collection and analyses were approved by our institutional review board (Ethical Review Board at Komagome hospital) in January 2020 (approval number: 2482). As the research was 
a retrospective review of chart data and specimens, and no personally identifiable information was included, the need to obtain written informed consent was waived.

\subsection{Pathological Evaluation}

We evaluated all the pathology slides of resected specimens. After fixing the specimens with $10 \%$ formalin and embedding them in paraffin, serial $4 \mu \mathrm{m}$ sections were stained with hematoxylin/eosin and elastica van Gieson to assess the degree of pleural and vascular invasion. When required, we also stained the sections with D2-40 to evaluate the extent of lymphatic permeation. The cases were reviewed according to the 4th edition of the World Health Organization histological classification and staged according to the 8th edition of the TNM classification of the Union for International Cancer Control.

\subsection{Follow-Up}

All patients were followed-up at our outpatient department quarterly in the first two years after resection and semi-annually thereafter. Contrast-enhanced CT scans of the chest and upper abdomen were routinely obtained during every scheduled outpatient visit for follow-up. CT or magnetic resonance imaging (MRI) of the brain were also routinely performed semi-annually. Such radiological examinations were also performed when neurological symptoms occurred or when clinical suspicions were raised. Once any metastasis was discovered, a routine examination such as PET was performed to determine the presence of other metastatic sites, if any.

Local recurrence was defined as tumor recurrence in contiguous anatomical sites, including the ipsilateral hemithorax and mediastinum after resection. Distant metastasis was defined as tumor recurrence in the contralateral lung or outside the hemithorax and mediastinum after resection. If both local and distant recurrences were noted within three months at the time of initial recurrence, these cases were classified into the distant metastasis group or the multiple metastatic group in number analysis (single vs. multiple). The location of recurrence at the time of final recurrence was defined as all organs where metastatic tumors were identified by the time of death or the last follow-up, regardless of the treatment effect. For patients who did not undergo resection or biopsy to confirm tumor recurrence, judgment was made according to the clinical course, progression, or aggressive clinical behavior.

\subsection{Statistical Analysis}

The length of organ-specific metastasis-free survival (time to recurrence) was defined as the interval between the date of resection and the date of the specific organ sites of metastasis (i.e., mediastinal lymph nodes, lungs, brain, bones, or liver) or the last follow-up. The length of survival after recurrence was defined as the interval between the date when recurrence was identified and the date of death or the last follow-up. Survival curves were drawn using the Kaplan-Meier method. The log-rank test was used to perform comparisons. To investigate the association between clinicopathological factors and specific organ sites of metastasis, clinicopathological factors were analyzed using the chi-squared/Fisher tests and multivariate logistic regression test. For specific organ site metastasis-free survival, univariate and multivariate analyses were performed using the Cox proportional hazards model. All variables with $p<0.1$ on univariate analysis were entered into the multivariate forward-backward stepwise model. Statistical significance was defined as $p<0.05$. All analyses were performed using SPSS software (version 25; IBM, Armonk, NY, USA).

\section{Results}

\subsection{Organ-specific Recurrence}

Considering organ-specific recurrence, the results of univariate (chi-squared tests) and multivariate (multiple logistic regression tests) analyses in all cases $(n=688)$ and recurrence cases $(n=223)$ are shown in Tables $2-7$ and Table S1. Both at the time of initial and final recurrence, node-positive 
NSCLCs recurred more often in the mediastinal lymph nodes (HR: 5.46, $p=0.001$; and HR: 4.59, $p=0.001$ in all cases, HR: 2.98, $p=0.001$; and HR: 2.45, $p=0.002$ in recurrence cases, respectively), and NSCLCs with pulmonary metastasis at surgery relapsed significantly more often in the lungs (HR: 2.11, $p=0.042$; and HR: 2.01, $p=0.044$ in all cases, HR: 2.80, $p=0.041$; and HR: 2.82, $p=0.046$ in recurrence cases, respectively). On evaluating typical distant organ metastasis, the factors correlated with brain metastasis both at initial and final recurrence included young age (HR: 2.39, $p=0.010$; and HR: 1.98, $p=0.017$ in all cases, HR: 2.28, $p=0.021$; and HR: 2.09, $p=0.017$ in recurrence cases, respectively), adenocarcinoma (HR: 2.65, $p=0.018$; and HR: 4.37, $p=0.001$ in all cases, HR: 2.45, $p=0.038$; and HR: $4.72, p=0.001$ in recurrence cases, respectively), and tumors with vascular invasion (HR: 6.45, $p=0.001$; and HR: 4.27, $p=0.001$ in all cases, HR: 3.09, $p=0.029$; and HR: 3.07, $p=0.006$ in recurrence cases, respectively). Although no variable was associated with bone metastasis in recurrence cases, vascular invasion in surgical specimens was associated with postoperative liver metastasis both at initial and final recurrence (HR: 9.85, $p=0.001$; and HR: 7.58, $p=0.007$ in all cases, HR: 5.85, $p=0.001$; and HR: 2.59, $p=0.055$ in recurrence cases, respectively) and adrenal gland metastasis (HR: 8.86, $p=0.001$; and HR: 7.90, $p=0.001$ in all cases, HR: 6.86, $p=0.001$; and HR: 7.95, $p=0.001$ in recurrence cases, respectively) (Tables $2-7$ and Table S1).

Table 2. Relationship between clinicopathologic factors and organ-specific recurrence (mediastinal lymph node) on multivariate logistic regression test.

\begin{tabular}{|c|c|c|c|c|c|c|c|c|c|}
\hline \multicolumn{10}{|c|}{ Mediastinal Lymph Node Metastasis } \\
\hline \multirow{3}{*}{ Factor } & & \multicolumn{4}{|c|}{ All Cases } & \multicolumn{4}{|c|}{ Recurrence Cases } \\
\hline & & \multicolumn{2}{|c|}{ Initial Recurrence } & \multicolumn{2}{|c|}{ Final Recurrence } & \multicolumn{2}{|c|}{ Initial Recurrence } & \multicolumn{2}{|c|}{ Final Recurrence } \\
\hline & & HR $(95 \%$ CI) & $p$ & HR $(95 \%$ CI) & $p$ & HR $(95 \% \mathrm{CI})$ & $p$ & HR $(95 \%$ CI $)$ & $p$ \\
\hline Sex & $\begin{array}{c}\text { male } \\
\text { female }\end{array}$ & $\begin{array}{c}1.92 \\
(1.03-3.56) \\
1\end{array}$ & 0.004 & - & & $\begin{array}{c}2.11 \\
(1.11-4.05) \\
1\end{array}$ & 0.025 & - & \\
\hline $\begin{array}{l}\text { Pleural } \\
\text { invasion }\end{array}$ & $\begin{array}{l}\text { present } \\
\text { absent }\end{array}$ & $\begin{array}{c}3.01 \\
(1.72-5.26) \\
1\end{array}$ & 0.001 & $\begin{array}{c}3.48 \\
(2.05-5.92) \\
1\end{array}$ & 0.001 & - & & - & \\
\hline Invasive size & $\begin{array}{l}>3 \mathrm{~cm} \\
\leq 3 \mathrm{~cm}\end{array}$ & $\begin{array}{c}1.81 \\
(1.02-3.21) \\
1\end{array}$ & 0.043 & $\begin{array}{c}1.94 \\
(1.14-3.30) \\
1\end{array}$ & 0.014 & - & & - & \\
\hline $\begin{array}{l}\text { Lymph node } \\
\text { metastasis }\end{array}$ & $\begin{array}{l}\text { present } \\
\text { absent }\end{array}$ & $\begin{array}{c}5.46 \\
(3.09-9.62) \\
1\end{array}$ & 0.001 & $\begin{array}{c}4.59 \\
(2.70-7.81) \\
1\end{array}$ & 0.001 & $\begin{array}{c}2.98 \\
(1.62-5.50) \\
1\end{array}$ & 0.001 & $\begin{array}{c}2.45 \\
(1.38-4.35) \\
1\end{array}$ & 0.002 \\
\hline
\end{tabular}

Table 3. Relationship between clinicopathologic factors and organ-specific recurrence (lung) on multivariate logistic regression test.

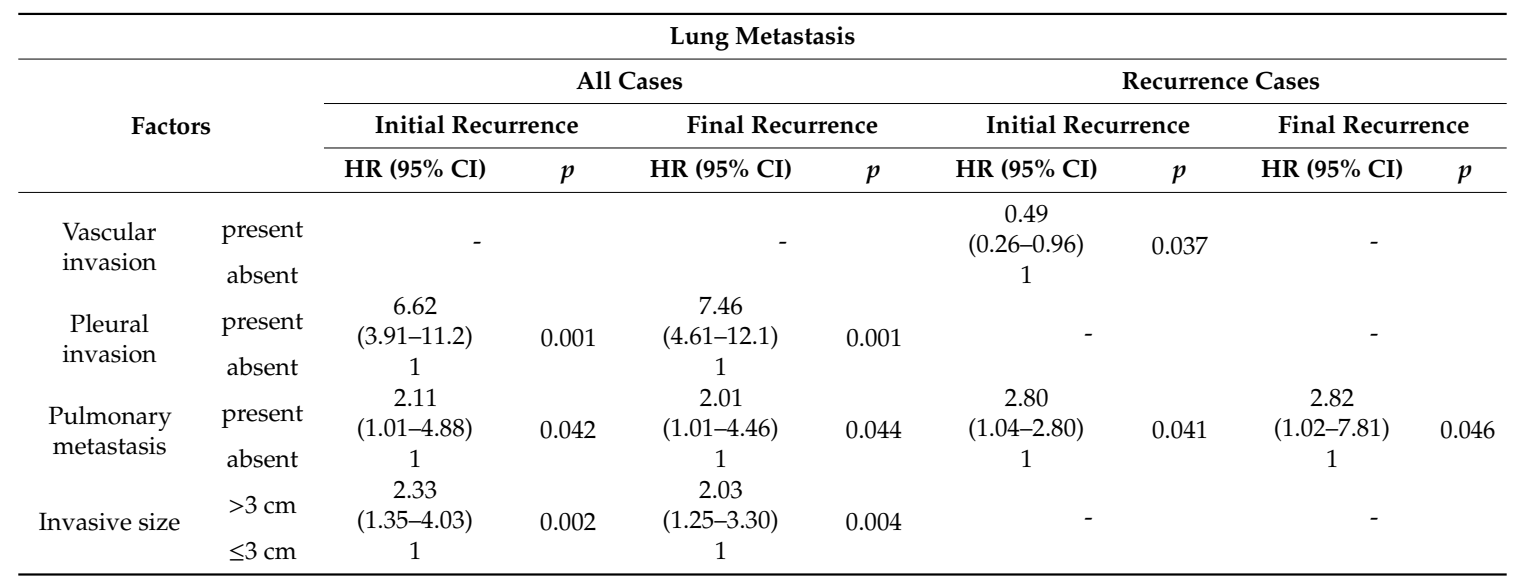


Table 4. Relationship between clinicopathologic factors and organ-specific recurrence (brain) on multivariate logistic regression test.

\begin{tabular}{|c|c|c|c|c|c|c|c|c|c|}
\hline \multicolumn{10}{|c|}{ Brain Metastasis } \\
\hline \multirow{3}{*}{ Factor } & & \multicolumn{4}{|c|}{ All Cases } & \multicolumn{4}{|c|}{ Recurrence Cases } \\
\hline & & \multicolumn{2}{|c|}{ Initial Recurrence } & \multicolumn{2}{|c|}{ Final Recurrence } & \multicolumn{2}{|c|}{ Initial Recurrence } & \multicolumn{2}{|c|}{ Final Recurrence } \\
\hline & & HR $(95 \%$ CI) & $p$ & HR $(95 \%$ CI $)$ & $p$ & HR $(95 \%$ CI $)$ & $p$ & HR $(95 \%$ CI) & $p$ \\
\hline Age & $\begin{array}{l}\geq 70 \\
<70\end{array}$ & $\begin{array}{c}0.42 \\
(0.22-0.81) \\
1\end{array}$ & 0.010 & $\begin{array}{c}0.51 \\
(0.29-0.87) \\
1\end{array}$ & 0.017 & $\begin{array}{c}0.44 \\
(0.22-0.88) \\
1\end{array}$ & 0.021 & $\begin{array}{c}0.48 \\
(0.26-0.88) \\
1\end{array}$ & 0.017 \\
\hline Pathology & $\begin{array}{c}\mathrm{AD} \\
\text { others }\end{array}$ & $\begin{array}{c}2.65 \\
(1.18-5.96) \\
1\end{array}$ & 0.018 & $\begin{array}{c}4.37 \\
(2.10-9.06) \\
1\end{array}$ & 0.001 & $\begin{array}{c}2.45 \\
(1.05-5.68) \\
1\end{array}$ & 0.038 & $\begin{array}{c}4.77 \\
(2.20-10.1) \\
1\end{array}$ & 0.001 \\
\hline $\begin{array}{l}\text { Vascular } \\
\text { invasion }\end{array}$ & $\begin{array}{c}\text { present } \\
\text { absent }\end{array}$ & $\begin{array}{c}6.45 \\
(2.42-17.2) \\
1\end{array}$ & 0.001 & $\begin{array}{c}4.27 \\
(2.02-9.01) \\
1\end{array}$ & 0.001 & $\begin{array}{c}3.09 \\
(1.12-8.48) \\
1\end{array}$ & 0.029 & $\begin{array}{c}3.07 \\
(1.38-6.80) \\
1\end{array}$ & 0.006 \\
\hline $\begin{array}{l}\text { Pleural } \\
\text { invasion }\end{array}$ & $\begin{array}{l}\text { present } \\
\text { absent }\end{array}$ & $\begin{array}{c}2.68 \\
(1.40-5.13) \\
1\end{array}$ & 0.003 & $\begin{array}{c}4.41 \\
(2.53-7.69) \\
1\end{array}$ & 0.001 & - & & - & \\
\hline $\begin{array}{l}\text { Pathological } \\
\text { stage }\end{array}$ & $\begin{array}{c}\text { II-III } \\
\text { I }\end{array}$ & -5 & & $\begin{array}{c}2.11 \\
(1.13-3.96) \\
1\end{array}$ & 0.010 & - & & - & \\
\hline
\end{tabular}

Table 5. Relationship between clinicopathologic factors and organ-specific recurrence (bone) on multivariate logistic regression test.

\begin{tabular}{|c|c|c|c|c|c|c|c|c|c|}
\hline \multicolumn{10}{|c|}{ Bone Metastasis } \\
\hline \multirow{3}{*}{\multicolumn{2}{|c|}{ Factors }} & \multicolumn{4}{|c|}{ All Cases } & \multicolumn{4}{|c|}{ Recurrence Cases } \\
\hline & & \multicolumn{2}{|c|}{ Initial Recurrence } & \multicolumn{2}{|c|}{ Final Recurrence } & \multicolumn{2}{|c|}{ Initial Recurrence } & \multicolumn{2}{|c|}{ Final Recurrence } \\
\hline & & HR (95\% CI) & $p$ & HR $(95 \%$ CI) & $p$ & HR (95\% CI) & $p$ & HR $(95 \%$ CI) & $p$ \\
\hline $\begin{array}{l}\text { Vascular } \\
\text { invasion }\end{array}$ & $\begin{array}{c}\text { present } \\
\text { absent }\end{array}$ & $\begin{array}{c}2.95 \\
(1.08-8.07) \\
1\end{array}$ & 0.037 & $\begin{array}{c}2.45 \\
(1.21-4.95) \\
1\end{array}$ & 0.013 & - & & - & \\
\hline $\begin{array}{l}\text { Pleural } \\
\text { invasion }\end{array}$ & $\begin{array}{c}\text { present } \\
\text { absent }\end{array}$ & $\begin{array}{c}5.32 \\
(2.53-11.2) \\
1\end{array}$ & 0.001 & $\begin{array}{c}4.00 \\
(2.24-7.14) \\
1\end{array}$ & 0.001 & - & & - & \\
\hline
\end{tabular}

Table 6. Relationship between clinicopathologic factors and organ-specific recurrence (liver) on multivariate logistic regression test.

\begin{tabular}{|c|c|c|c|c|c|c|c|c|c|}
\hline \multicolumn{10}{|c|}{ Liver Metastasis } \\
\hline \multirow{3}{*}{\multicolumn{2}{|c|}{ Factors }} & \multicolumn{4}{|c|}{ All Cases } & \multicolumn{4}{|c|}{ Recurrence Cases } \\
\hline & & \multicolumn{2}{|c|}{ Initial Recurrence } & \multicolumn{2}{|c|}{ Final Recurrence } & \multicolumn{2}{|c|}{ Initial Recurrence } & \multicolumn{2}{|c|}{ Final Recurrence } \\
\hline & & HR $(95 \%$ CI) & $p$ & HR $(95 \%$ CI) & $p$ & HR $(95 \%$ CI $)$ & $p$ & $\operatorname{HR}(95 \% \mathrm{CI})$ & $p$ \\
\hline $\begin{array}{l}\text { Vascular } \\
\text { invasion }\end{array}$ & $\begin{array}{c}\text { present } \\
\text { absent }\end{array}$ & $\begin{array}{c}9.85 \\
(3.90-58.6) \\
1\end{array}$ & 0.001 & $\begin{array}{c}7.58 \\
(1.74-33.3) \\
1\end{array}$ & 0.007 & $\begin{array}{c}5.85 \\
(1.86-12.5) \\
1\end{array}$ & 0.001 & $\begin{array}{c}2.59 \\
(0.96-7.45) \\
1\end{array}$ & 0.055 \\
\hline $\begin{array}{l}\text { Pleural } \\
\text { invasion }\end{array}$ & $\begin{array}{l}\text { present } \\
\text { absent }\end{array}$ & $\begin{array}{c}3.257 \\
(1.33-7.94) \\
1\end{array}$ & 0.010 & $\begin{array}{c}2.70 \\
(1.20-6.06) \\
1\end{array}$ & 0.016 & - & & - & \\
\hline
\end{tabular}

Table 7. Relationship between clinicopathologic factors and organ-specific recurrence (adrenal gland) on multivariate logistic regression test.

\begin{tabular}{|c|c|c|c|c|c|c|c|c|c|}
\hline \multicolumn{10}{|c|}{ Adrenal Gland Metastasis } \\
\hline \multirow{3}{*}{\multicolumn{2}{|c|}{ Factors }} & \multicolumn{4}{|c|}{ All Cases } & \multicolumn{4}{|c|}{ Recurrence Cases } \\
\hline & & \multicolumn{2}{|c|}{ Initial Recurrence } & \multicolumn{2}{|c|}{ Final Recurrence } & \multicolumn{2}{|c|}{ Initial Recurrence } & \multicolumn{2}{|c|}{ Final Recurrence } \\
\hline & & HR $(95 \%$ CI $)$ & $p$ & HR $(95 \%$ CI) & $p$ & HR $(95 \% \mathrm{CI})$ & $p$ & HR $(95 \%$ CI $)$ & $p$ \\
\hline $\begin{array}{l}\text { Vascular } \\
\text { invasion }\end{array}$ & $\begin{array}{l}\text { present } \\
\text { absent }\end{array}$ & $\begin{array}{c}8.86 \\
(3.14-53.5) \\
1\end{array}$ & 0.001 & $\begin{array}{c}7.99 \\
(3.42-40.5) \\
1\end{array}$ & 0.001 & $\begin{array}{c}6.86 \\
(2.15-13.5) \\
1\end{array}$ & 0.001 & $\begin{array}{c}7.95 \\
(3.23-20.5) \\
1\end{array}$ & 0.001 \\
\hline $\begin{array}{l}\text { Pleural } \\
\text { invasion }\end{array}$ & $\begin{array}{l}\text { present } \\
\text { absent }\end{array}$ & $\begin{array}{c}3.32 \\
(1.03-10.6) \\
1\end{array}$ & 0.044 & $\begin{array}{c}3.45 \\
(1.28-9.35) \\
1\end{array}$ & 0.014 & - & & - & \\
\hline
\end{tabular}

AD, adenocarcinoma; HR, Hazard ratio; 95\% CI, 95\% confidence interval. 


\subsection{Location (Local vs. Distant) and Numbers (Single vs. Multiple) of Recurrence Sites}

We focused on the recurrence cases hereafter. The clinicopathological factors and location (local vs. distant) at the time of initial recurrence were not significantly correlated (Table 8). However, multiple metastases at the time of initial recurrence were observed after resection of advanced stage NSCLC (hazard ratio (HR): 2.57, $p=0.012$ ). On evaluating all recurrence sites at the time of final observation, adenocarcinoma (HR: 2.06, $p=0.016$ ) and the presence of lymphatic permeation (HR: 1.75, $p=0.048$ ) were risk factors for multiple recurrence (Table 9).

Table 8. The Relationship between clinicopathological factors and recurrence patterns (locations and numbers) at initial recurrence and final recurrence on chi-squared/Fisher test.

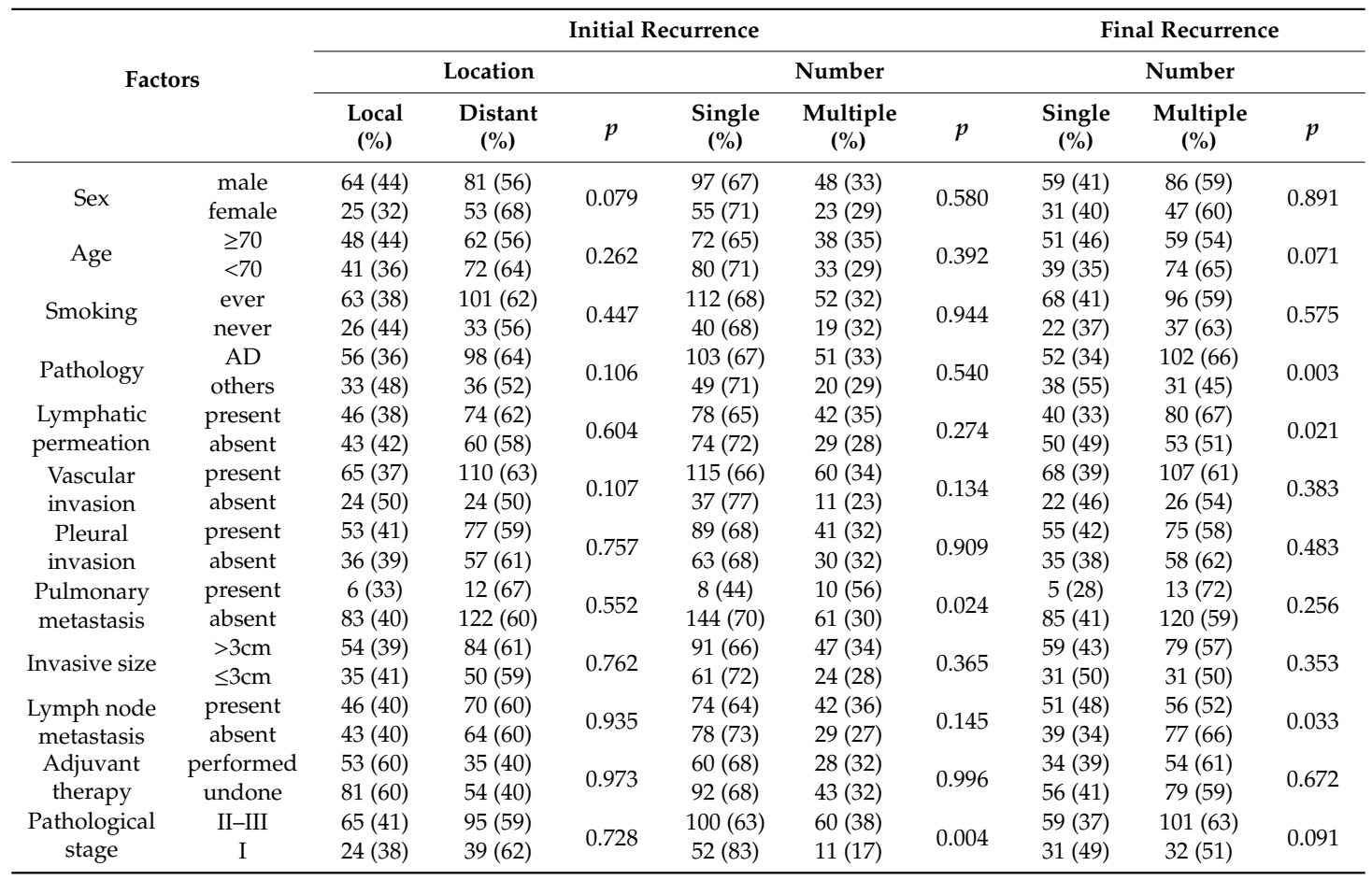

Table 9. Risk factors of multiple metastasis on multivariate logistic regression test.

\begin{tabular}{|c|c|c|c|c|c|}
\hline & & \multicolumn{4}{|c|}{ Multiple Metastasis } \\
\hline \multicolumn{2}{|c|}{ Factors } & \multicolumn{2}{|c|}{ Initial Recurrence } & \multicolumn{2}{|c|}{ Final Recurrence } \\
\hline & & HR (95\% CI) & $p$ & HR $(95 \%$ CI) & $p$ \\
\hline Pathology & $\begin{array}{c}\text { AD } \\
\text { Others }\end{array}$ & & & $\begin{array}{c}2.06(1.14-3.69) \\
1\end{array}$ & 0.016 \\
\hline $\begin{array}{l}\text { Lymphatic } \\
\text { permeation }\end{array}$ & $\begin{array}{c}\text { Present } \\
\text { absent }\end{array}$ & & & $\begin{array}{c}1.75(1.00-3.03) \\
1\end{array}$ & 0.048 \\
\hline $\begin{array}{l}\text { Pathological } \\
\text { stage }\end{array}$ & $\begin{array}{c}\text { II-III } \\
\text { I }\end{array}$ & $\begin{array}{c}2.57(1.23-5.36) \\
1\end{array}$ & 0.012 & - & \\
\hline
\end{tabular}

AD, adenocarcinoma; HR, Hazard ratio; 95\% CI, 95\% confidence interval.

\subsection{Time to Recurrence}

Among the cases with recurrence, some clinicopathological factors were correlated with early recurrence, as shown in Table 10 and Table S2 and Figure 1. On multivariate analysis, the presence of vascular invasion (HR: 1.56, $p=0.008$ ), larger invasive size (HR: 1.37, $p=0.028$ ), and advanced stage (HR: $1.43, p=0.027$ ) were independent risk factors of early recurrence among recurrent cases (Table 4 and Table S2). 
Table 10. Multivariate analysis of time to recurrence and survival after recurrence according to the clinicopathological factors.

\begin{tabular}{|c|c|c|c|c|c|c|c|c|}
\hline \multicolumn{9}{|c|}{ Multivariate Analysis } \\
\hline \multicolumn{2}{|c|}{ Factors } & \multirow{2}{*}{$n$} & \multicolumn{3}{|c|}{ Time to Recurrence } & \multicolumn{3}{|c|}{ Survival after Recurrence } \\
\hline & & & $\begin{array}{l}\text { Median Months } \\
\text { (Range) }\end{array}$ & HR $(95 \%$ CI) & $p$ & $\begin{array}{l}\text { Median Months } \\
\text { (Range) }\end{array}$ & HR (95\% CI) & $p$ \\
\hline \multirow{2}{*}{ Age } & $\geq 70$ & 110 & $12(1-95)$ & \multirow{2}{*}{\multicolumn{2}{|c|}{-}} & $13(0-83)$ & $1.99(1.39-2.85)$ & \multirow{2}{*}{0.001} \\
\hline & $<70$ & 113 & $12(1-119)$ & & & $25(0-182)$ & 1 & \\
\hline \multirow{2}{*}{ Pathology } & $\mathrm{AD}$ & 154 & $17(1-119)$ & \multirow{2}{*}{\multicolumn{2}{|c|}{-}} & $23.5(0-180)$ & $0.51(0.36-0.74)$ & \multirow{2}{*}{0.001} \\
\hline & others & 69 & $10(1-95)$ & & & $10(1-182)$ & 1 & \\
\hline \multirow{2}{*}{$\begin{array}{l}\text { Vascular } \\
\text { invasion }\end{array}$} & present & 175 & $11(1-107)$ & \multirow{2}{*}{$\begin{array}{c}1.56 \\
(1.12-2.17) \\
1\end{array}$} & \multirow{2}{*}{0.008} & $17(0-182)$ & $1.61(1.00-2.36)$ & \multirow{2}{*}{0.048} \\
\hline & absent & 48 & $24(1-119)$ & & & $21(1-121)$ & 1 & \\
\hline \multirow{2}{*}{ Invasive size } & $>3 \mathrm{~cm}$ & 138 & $11(1-119)$ & \multirow{2}{*}{$\begin{array}{c}1.37 \\
(1.03-1.82) \\
1\end{array}$} & \multirow{2}{*}{0.028} & $17(0-182)$ & \multirow[t]{2}{*}{ - } & \\
\hline & $\leq 3 \mathrm{~cm}$ & 85 & $19(1-107)$ & & & $21(0-121)$ & & \\
\hline \multirow{2}{*}{$\begin{array}{l}\text { Pathological } \\
\text { stage }\end{array}$} & II-III & 160 & $11(1-80)$ & \multirow{2}{*}{$\begin{array}{c}1.43 \\
(1.04-1.96) \\
1\end{array}$} & \multirow{2}{*}{0.027} & $17(0-182)$ & \multirow{2}{*}{-} & \\
\hline & I & 63 & $23(3-119)$ & & & $21(1-115)$ & & \\
\hline
\end{tabular}

AD, adenocarcinoma; HR, Hazard Ratio; 95\% CI, 95\% confidence interval.

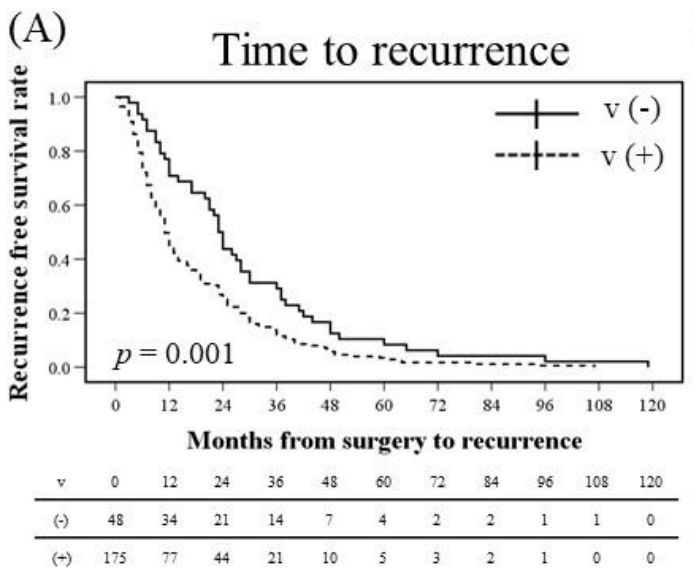

(B)

Time after recurrence

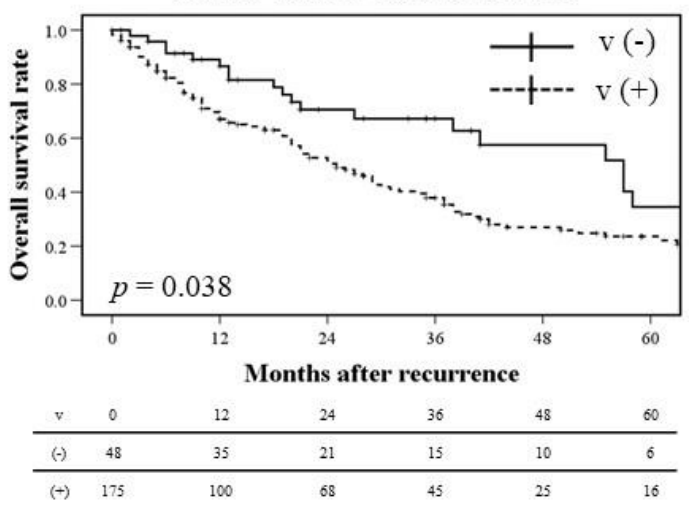

Figure 1. Survival curves of time to recurrence (A) and time after recurrence (B), according to vascular invasion. $\mathrm{V}$, vascular invasion.

\subsection{Survival after Recurrence}

In addition to time to recurrence, vascular invasion was an unfavorable prognostic factor even after recurrence on multivariate analysis (HR: 1.61, $p=0.048$; Table 4 and Table S2 and Figure 1). Old age and non-adenocarcinoma cases were also poor prognostic factors (HR: 1.99, $p=0.001$; and HR: 1.95, $p=0.001$, respectively)

\section{Discussion}

The results of the current study demonstrated a strong correlation between some perioperative clinicopathological factors and recurrence patterns including the location and number of metastases at the time of initial and final recurrence. Although a couple of studies have shown various predictors of brain metastasis after complete resection, few studies have shown that NSCLC preferentially relapses to other organs including mediastinal lymph nodes, liver, and adrenal gland on systemic evaluation of recurrence sites [15-18]. Hung et al. demonstrated that the pathological subtypes of lung adenocarcinoma are associated with organ-specific metastasis in patients with resected lung adenocarcinoma with distant metastasis [19]. They included all surgery cases regardless of recurrence into survival analyses to calculate the HR of organ-specific recurrence and reported some clinicopathological factors that were independently correlated with organ-specific recurrence. For determining concise and true risk factors of organ-specific recurrence, only cases of recurrence 
should be also analyzed, as was done in the current study because almost all resected tumors without recurrence during a certain observation period after surgery may not have potential to metastasize. It would be very important and intriguing to analyze those factors among recurrence cases, which definitely have potential for metastasis. Moreover, most studies focused only on the site of initial recurrence; they did not focus on the organs showing late recurrence. In the current study, we distinguished between initial and final recurrence sites. Although there were no apparent differences in the risk factors for the initial and final recurrence sites, to the best of our knowledge, the current study is the first to evaluate the metastatic lesions until the end of the follow-up period.

The mediastinal lymph nodes, lungs, brain, bones, adrenal gland are the most common organ sites of metastasis of resected NSCLC [10-14]. Regarding intrathoracic recurrence, mediastinal lymph node recurrence is associated with node-positive NSCLC resection whereas pulmonary metastasis at the time of surgery was associated with lung recurrence. These two sites, i.e., the mediastinal lymph nodes and lungs, were the most common sites of metastases in the current study. Enhanced CT was helpful for detecting these types of metastases during follow-up. Brain metastasis is the most serious issue in patients because it contributes to the decrease in the quality of life. In fact, some studies have evaluated various predictors for brain metastasis after complete resection [15-18]. For example, Hubbs et al. showed that young age, larger tumor size, lymphovascular invasion, and hilar lymph node involvement were associated with an increased risk of brain metastasis [15]. Although this result is very similar to those obtained in the current study, these factors were compared among all resected cases (not only recurrence cases) and vascular invasion and/or lymphatic permeation was considered 'lymphovascular invasion' [7]. On survival analyses as well as on evaluating the risk factors for organ-specific recurrence, vascular invasion and lymphatic permeation have different significance as risk factors, suggesting that these two pathological factors should be distinguished considering the biology of NSCLC. Among cases of adenocarcinoma, micropapillary-predominant adenocarcinoma was significantly associated with a higher incidence of brain metastasis [19]. In the current study, no such tendency was found, and only four patients had micropapillary-predominant adenocarcinoma. The incidence of adenocarcinoma subtypes may differ among countries. Anyway, this information is important and helpful for identifying patients with resected lung adenocarcinoma who are at a higher risk of developing brain metastases because early diagnosis of brain metastasis is difficult in patients without neurologic symptoms.

While the liver was not the most common organ site of metastasis of lung cancer, liver metastasis was observed during follow-up after surgery. Few studies have evaluated liver metastasis after the resection of NSCLC. Vascular invasion was an independent risk factor for liver metastasis as well as brain and adrenal gland metastasis. Small malignant nodules in the liver are usually difficult to differentiate from benign liver cysts. Hence, if follow-up CT reveals a liver nodule after the resection of NSCLC with vascular invasion, additional examination is required.

Regarding numbers of recurrence sites, even though tumor relapsed postoperatively, single recurrence site was found more frequently among non-adenocarcinomas, NSCLCs without lymphatic permeation, and those with lymph node metastasis at surgery when observed for long period as shown in Table 3. Locoregional treatment such as surgery and radiation for such cases would be effective to control and manage recurred tumor.

Among metastatic cases of NSCLC, vascular invasion, large invasive size, and advanced stage were independent risk factors of early recurrence. Although these factors and others-such as lymphatic permeation and pleural invasion-are known prognostic factors for recurrence-free survival, the risk factors for early recurrence have not been evaluated previously [5-9]. Cases of NSCLC with vascular invasion would require frequent examination including systemic radiological evaluation. Moreover, vascular invasion is significantly associated with shorter survival after recurrence. However, till date, no biomarker has been found for post-recurrence survival. Hence, careful follow-up after recurrence is required in cases with vascular invasion. 
The current study has some limitations and biases. Because the study was retrospective and performed at a single institute, patient selection bias and time trend bias were inevitable. Genetic information such as driver mutations and immunogenic status including programmed cell death 1/programmed cell death 1 ligand 1 status were not evaluated since not all cases had this information. In addition, the study might have had diagnostic bias, as conventional imaging including full-body CT could not always identify all metastatic lesions. There was also bias in distinguishing second primary lung cancer from recurrent NSCLC. Last, although cases with postoperative radiation for prevention of local recurrence were not included, clinical effect of postoperative systemic chemotherapy was not considered because systemic treatment would not change preferential patterns of recurrence.

\section{Conclusions}

In conclusion, the results of the current study demonstrate that some clinicopathological factors were associated with organ-specific metastasis, number of metastasis sites, and post-recurrence survival. This information is important for determining which patients need follow-up with shorter period systemic evaluation and further studies regarding the molecular mechanisms that lead to organ-specific metastasis in NSCLC.

Supplementary Materials: The following are available online at http://www.mdpi.com/2077-0383/9/8/2473/s1, Table S1: Relationship between clinicopathologic factors and organ-specific recurrence (A, mediastinal lymph node; B, lung; C, brain; D, bone; E, liver; and F, adrenal gland) on chi-squared/Fisher test. Table S2: Univariate analysis of time to recurrence and survival after recurrence according to the clinicopathological factors.

Author Contributions: Conceptualization, R.S. and T.K.; methodology, T.K.; software, U.M.; validation, T.K. and H.H.; formal analysis, T.K.; investigation, R.S.; resources, N.S. and M.U.; data curation, Y.S. and T.S.; writing — original draft preparation, R.S. and T.K.; writing—review and editing, M.H., T.H, and H.H.; visualization, T.K.; supervision, T.H., and H.H.; project administration, T.H., and H.H.; funding acquisition, none. All authors have read and agreed to the published version of the manuscript.

Funding: This research received no external funding.

Conflicts of Interest: The authors declare no conflict of interest.

\section{References}

1. Oudkerk, M.; Devaraj, A.; Vliegenthart, R.; Henzler, T.; Prosch, H.; Heussel, C.P.; Bastarrika, G.; Sverzellati, N.; Mascalchi, M.; Delorme, S.; et al. European position statement on lung cancer screening. Lancet Oncol. 2017, 18, e754-e766. [CrossRef]

2. Yang, D.; Liu, Y.; Bai, C.; Wang, X.; Powell, C.A. Epidemiology of lung cancer and lung cancer screening programs in China and the United States. Cancer Lett. 2020, 468, 82-87. [CrossRef] [PubMed]

3. Strauss, G.M.; Herndon, J.E., II; Maddaus, M.A.; Johnstone, D.W.; Johnson, E.A.; Harpole, D.H.; Gillenwater, H.H.; Watson, D.M.; Sugarbaker, D.J.; Schilsky, R.L.; et al. Adjuvant Paclitaxel plus Carboplatin Compared with Observation in Stage IB Non-Small-Cell Lung Cancer: CALGB 9633 with the Cancer and Leukemia Group B, Radiation Therapy Oncology Group, and North Central Cancer Treatment Group Study Groups. J. Clin. Oncol. 2008, 26, 5043-5051. [CrossRef] [PubMed]

4. Winton, T.; Livingston, R.; Johnson, D.; Rigas, J.; Johnston, M.; Butts, C.; Cormier, Y.; Goss, G.; Inculet, R.; Vallieres, E.; et al. Vinorelbine plus cisplatin vs. observation in resected non-small-cell lung cancer. N. Engl. J. Med. 2005, 352, 2589-2597. [CrossRef] [PubMed]

5. Kinoshita, T.; Ohtsuka, T.; Yotsukura, M.; Asakura, K.; Goto, T.; Kamiyama, I.; Otake, S.; Tajima, A.; Emoto, K.; Hayashi, Y.; et al. Prognostic impact of preoperative tumor marker levels and lymphovascular invasion in pathological stage I adenocarcinoma and squamous cell carcinoma of the lung. J. Thorac. Oncol. 2015, 10, 619-628. [CrossRef] [PubMed]

6. Tsutani, Y.; Suzuki, K.; Koike, T.; Wakabayashi, M.; Mizutani, T.; Aokage, K.; Saji, H.; Nakagawa, K.; Zenke, Y.; Takamochi, K.; et al. High-risk factors for recurrence of stage I lung adenocarcinoma: Follow-up data from JCOG0201. Ann. Thorac. Surg. 2019, 108, 1484-1490. [CrossRef] [PubMed] 
7. Kinoshita, T.; Yoshida, J.; Ishii, G.; Aokage, K.; Hishida, T.; Nagai, K. The differences of biological behavior based on the clinicopathological data between resectable large-cell neuroendocrine carcinoma and small-cell lung carcinoma. Clin. Lung Cancer 2013, 14, 535-540. [CrossRef] [PubMed]

8. Harada, M.; Hato, T.; Horio, H. Intratumoral lymphatic vessel involvement is an invasive indicator of completely resected pathologic stage I non-small cell lung cancer. J. Thorac. Oncol. 2011, 6, 48-54. [CrossRef] [PubMed]

9. Kinoshita, T.; Ohtsuka, T.; Hato, T.; Goto, T.; Kamiyama, I.; Tajima, A.; Emoto, K.; Hayashi, Y.; Kohno, M. Prognostic factors based on clinicopathological data among the patients with resected peripheral squamous cell carcinomas of the lung. J. Thorac. Oncol. 2014, 9, 1779-1787. [CrossRef] [PubMed]

10. Yoshino, I.; Yohena, T.; Kitajima, M.; Ushijima, C.; Nishioka, K.; Ichinose, Y.; Sugimachi, K. Survival of non-small cell lung cancer patients with postoperative recurrence at distant organs. Ann. Thorac. Cardiovasc. Surg. 2001, 7, 204-209. [PubMed]

11. Hung, J.J.; Hsu, W.H.; Hsieh, C.C.; Huang, B.S.; Huang, M.H.; Liu, J.S.; Wu, Y.C. Post-recurrence survival in completely resected stage I non-small cell lung cancer with local recurrence. Thorax 2009, 64, $192-196$. [CrossRef] [PubMed]

12. Cho, S.; Yum, S.; Kim, K.; Jheon, S. Prognostic factors for post-recurrence survival in patients with completely resected Stage III (N2) non-small-cell lung cancer. Eur. J. Cardiothorac. Surg. 2018, 54, 554-559. [CrossRef] [PubMed]

13. Song, I.H.; Yeom, S.W.; Heo, S.; Choi, W.S.; Yang, H.C.; Jheon, S.; Kim, K.; Cho, S. Prognostic factors for post-recurrence survival in patients with completely resected Stage I non-small-cell lung cancer. Eur. J. Cardiothorac. Surg. 2014, 45, 262-267. [CrossRef] [PubMed]

14. Shimada, Y.; Saji, H.; Yoshida, K.; Kakihana, M.; Honda, H.; Nomura, M.; Usuda, J.; Kajiwara, N.; Ohira, T.; Ikeda, N. Prognostic factors and the significance of treatment after recurrence in completely resected stage I non-small cell lung cancer. Chest 2013, 143, 1626-1634. [CrossRef] [PubMed]

15. Hubbs, J.L.; Boyd, J.A.; Hollis, D.; Chino, J.P.; Saynak, M.; Kelsey, C.R. Factors associated with the development of brain metastases: Analysis of 975 patients with early stage nonsmall cell lung cancer. Cancer 2010, 116, 5038-5046. [CrossRef] [PubMed]

16. Martini, N.; Bains, M.S.; Burt, M.E.; Zakowski, M.F.; McCormack, P.; Rusch, V.W.; Ginsberg, R.J. Incidence of local recurrence and second primary tumors in resected stage I lung cancer. J. Thorac. Cardiovasc. Surg. 1995, 109, 120-129. [CrossRef]

17. Figlin, R.A.; Piantadosi, S.; Feld, R.; Lung Cancer Study Group. Intracranial recurrence of carcinoma after complete surgical resection of stage I, II, and III non-small-cell lung cancer. N. Engl. J. Med. 1988, 318, 1300-1305. [CrossRef] [PubMed]

18. D'Amico, T.A.; Aloia, T.A.; Moore, M.B.H.; Conlon, D.H.; Herndon, J.E., II; Kinch, M.S.; Harpole, D.H., Jr. Predicting the sites of metastases from lung cancer using molecular biologic markers. Ann. Thorac. Surg. 2001, 72, 1144-1148. [CrossRef]

19. Hung, J.J.; Jeng, W.J.; Wu, Y.C.; Chou, T.Y.; Hsu, W.H. Factors predicting organ-specific distant metastasis in patients with completely resected lung adenocarcinoma. Oncotarget 2016, 7, 58261-58273. [CrossRef] [PubMed]

(C) 2020 by the authors. Licensee MDPI, Basel, Switzerland. This article is an open access article distributed under the terms and conditions of the Creative Commons Attribution (CC BY) license (http://creativecommons.org/licenses/by/4.0/). 